\title{
Pengaruh sistem tanam dan tinggi genangan air terhadap produktivitas tanaman padi kultivar Mekongga di Kabupaten Karawang
}

\section{Effect of planting system and flooding on productivity of paddy cultivar Mekongga in Karawang District}

\author{
Diterima : 5 Juli 2018/Disetujui : 4 Agustus 2018 / Dipublikasikan : 7 Agustus 2018 \\ CDepartment of Crop Science, Padjadjaran University
}

\begin{abstract}
The program that increase food security is government target to supply national food needs. Rice is the staple food for most of Indonesia's population whose productivity must be increased. This study aims to obtain planting system and flooding that is able to provide the highest productivity in Mekongga rice cultivar in Karawang district. The research was conducted in the rice fields of Tanjung Bungin Village, Pakisjaya, Karawang Regency, West Java Province. It is 5 meters above sea level. This study was conducted from September 2016 until December 2016. The research method used was experiment method and experimental design used was Randomized Block Design, with nine treatments and repeated three times. There were combination of planting system and flooding for treatments. The results showed that planting system and flooding significantly affect crop height at 42,56 , and 70 day after planting (dap). Number of tillers at 42,56 , and 70 dap, number of panicles, number of grain per panicle, percentage of filled grain, and dried milled grain weight. Legowo 4: 1 planting system and $5 \mathrm{~cm}$ flooding gave highest yield of dried grain of 15.2 $\mathrm{kg} /$ plot or equal to 7.20 ton / ha.
\end{abstract}

Keywords: Flooding - Mekongga cultivar . Planting system

Sari. Program peningkatan ketahanan pangan diarahkan untuk dapat memenuhi kebutuhan pangan masyarakat di dalam negeri dari

\footnotetext{
Dikomunikasikan oleh Anne Nuraini

Laksono, R.A. ${ }^{1}$. Y. Irawan ${ }^{2}$

1 Program Studi Agroteknologi, Fakultas Pertanian,

Universitas Singaperbangsa Karawang

2 Perusahaan Umum Jasa Tirta II

Korespondensi: rommy.laksono@staff.unsika.ac.id
}

produksi pangan nasional. Salah satu bahan pangan nasional yang diupayakan ketersediaannya tercukupi sepanjang tahun adalah beras yang menjadi makanan pokok bagi sebagian besar penduduk Indonesia. Penelitian ini bertujuan untuk mendapatkan sistem tanam dan tinggi genangan air yang mampu memberikan produktivitas tertinggi pada tanaman padi varietas Mekongga di Kabupaten Karawang. Penelitian dilaksanakan di sawah teknis Desa Tanjung Bungin, Kecamatan Pakisjaya, Kabupaten Karawang, Provinsi Jawa Barat. Ketinggian tempat percobaan adalah 5 meter di atas permukaan laut. Penelitian dilaksanakan dari bulan September 2016 sampai dengan bulan Desember 2016. Metode penelitian yang digunakan adalah metode eksperimen dan rancangan percobaan yang digunakan adalah Rancangan Acak Kelompok faktor tunggal, dengan sembilan perlakuan yang diulang sebanyak tiga kali. Terdapat sembilan kombinasi perlakuan sistem tanam dan tinggi genangan air. Hasil penelitian menunjukkan sistem tanam dan tinggi genangan air tanaman padi (Oryza sativa L.) varietas Mekongga berpengaruh nyata terhadap tinggi tanaman 42, 56, dan 70 hst. Jumlah anakan umur 42, 56, dan 70 hst, jumlah malai per rumpun, jumlah gabah per malai, persentase gabah isi, dan hasil gabah kering giling. Sistem tanam Legowo 4:1 dan genangan air $5 \mathrm{~cm}$ memberikan hasil gabah kering giling tertinggi sebanyak $15,2 \mathrm{~kg} /$ petak atau setara dengan 7,20 ton/ha.

Kata kunci : Sistem tanam • Tinggi genangan air - Varietas Mekongga 


\section{Pendahuluan}

Program peningkatan ketahanan pangan menjadi target utama pemerintah dalam memenuhi kebutuhan masyarakat Indonesia. Beberapa program telah dilalui untuk mencapai ketahanan pangan diantaranya perbaikan jaringan irigasi, optimalisasi lahan, dan intensifikasi pertanian. Beras merupakan bahan pangan nasional yang menjadi target utama, karena masih menjadi bahan pangan pokok bagi hampir seluruh masyarakat Indonesia.

Propinsi Jawa Barat merupakan salah satu sentra padi yang memberikan kontribusi terbesar ketiga terhadap produksi beras nasional dengan kontribusi produksi rata-rata 16,13\% pada tiga tahun terakhir 2012-2015. Peranan kontribusi Jawa Barat sebagai penyumbang beras nasional terbesar ketiga, tidak lepas dari peran Kabupaten Karawang yang menyumbang beras rata-rata untuk Jawa Barat sebesar 1,2 juta ton, atau kontribusi Kabupaten Karawang sebesar 11,6 \% dari produksi Jawa Barat (Badan Pusat Statistik, 2016).

Sistim intensifikasi padi merupakan teknologi budidaya alternatif yang berpeluang besar untuk dapat meningkatkan produktivitas padi sawah di Indonesia, dimana metode ini terdapat perubahan dalam manajemen tanaman, tanah, air dan hara (Aqil, 2007).

Pengaturan sistem tanam merupakan faktor penting bagi pertumbuhan agar tidak terjadi persaingan tanaman (Pitoyo, 2013). Sistem tanam mempengaruhi populasi tanaman, efisiensi penggunaan cahaya, perkembangan hama penyakit dan kompetisi antara tanaman dalam penggunaan air dan unsur hara (Putra, 2011). Pengaturan sistem tanam dapat menghindari terjadinya tumpang tindih diantara tajuk tanaman, memberikan ruang bagi perkembangan akar dan tajuk tanaman dan meningkatkan efisiensi penggunaan benih. Pada tanah subur sistem tanam cenderung lebih lebar, sedangkan tanah yang kurang subur sistem tanam cenderung lebih rapat (Makarim dkk, 2007).

Sistim penanaman konvensional atau yang biasa disebut sistem tegel biasa dilakukan penggunaan sistem tanam $(25 \times 25) \mathrm{cm}$. Ada juga yang penggunaan jarak yang lebar $(30 \times 30) \mathrm{cm}$, hal tersebut tergantung dengan kondisi wilayah, musim dan penggunaan Kultivar yang ada pada tanaman (Balai Litbang Pertanian Jawa Barat, 2011). Beberapa cara penanaman dan pola penanaman padi yang sering diterapkan petani untuk bercocok tanam seperti sistem tanam $(25 \mathrm{x}$ $25) \mathrm{cm}$, sistem tanam $(30 \times 30) \mathrm{cm}$, dan sistem tanam jajar legowo 2:1 maupun legowo 4:1. Penggunaan sistem tanam dimaksudkan untuk memaksimalkan pertumbuhan pada tanaman sehingga pencapaian hasil tanaman lebih maksimal (Balai Irigasi, 2007). Hasil penelitian Devi Novi Astuti, (2011) mengemukakan bahwa sistem tanam akan berpengaruh terhadap produksi tanaman karena berkaitan dengan ketersediaan unsur hara, cahaya matahari serta ruang bagi tanaman. Sehingga perlu adanya suatu teknologi dan inovasi baru dalam produksi pertanian, yaitu dengan menggunakan pola sistem tanam dalam budidaya tanaman.

Ketersediaan air yang cukup merupakan salah satu faktor utama dalam produksi padi sawah. Di sebagian besar daerah Asia, tanaman padi tumbuh kurang optimum akibat kelebihan air atau kekurangan air karena curah hujan yang tidak menentu dan pola lanskap yang tidak teratur. Pada umumnya, alasan utama penggenangan pada budidaya padi sawah yaitu karena sebagian besar Kultivar padi sawah tumbuh lebih baik dan menghasilkan produktivitas yang lebih tinggi ketika tumbuh pada tanah tergenang dibandingkan dengan tanah yang tidak tergenang (Juliardi dan Ruskandar, 2006).

Kebutuhan air untuk proses pertumbuhan tanaman padi masih belum diketahui secara pasti jumlahnya. Hal tersebut menyebabkan petani melakukan pemberian air yang berlebihan pada lahan sawah. Pemberian air yang berlebihan dapat menimbulkan pemborosan penggunaan air. Cara untuk menjaga ketersediaan air tanpa menimbulkan pemborosan yaitu dengan mengatur tinggi penggenangan air. Uphoff (2002) menyatakan bahwa berdasarkan metode system of rice intensification (SRI) tinggi penggenangan minimum yaitu 1-2 $\mathrm{cm}$ dapat menghemat penggunaan air tanpa menurunkan produksi padi. Hasil penelitian Gani (2007) menunjukkan bahwa penggenangan dengan ketinggian 2-3 cm dapat meningkatkan hasil gabah sebesar dua kali lipat dibandingkan penggenangan 7-10 cm. Hal ini ditambahkan oleh Suhartatik dkk. (2011) yang menyatakan bahwa interval 2 hari penggenangan mempunyai pengaruh 98,85\% pada parameter bobot gabah kering giling dan produksi gabah kering giling per hektar. Lebih lanjut Zaini (2008) menyatakan bahwa, produktivitas lahan yang 
dilakukan penggenangan dengan ketinggian 5 $\mathrm{cm}$, dapat menghemat air hingga $21 \%$.

Kultivar yang memiliki prospek untuk menggantikan Kultivar Ciherang sebagai kultivar padi sawah utama yang ditanami petani adalah Kultivar Mekongga. Kultivar ini termasuk dalam golongan kultivar unggul baru yang belum dikenal masyarakat, khususnya para petani di Kabupaten Karawang, sehingga perlu diketahui bagaimana kemampuan adaptasinya jika ditanam di daerah Karawang dan dapat menjadi pilihan atau alternatif kultivar tanaman padi yang dapat ditanam dengan hasil yang lebih baik (Yudhi Mahmud dan Sulistyo Sidik Purnomo, 2014). Hasil Pengkajian Balai Penyuluhan Pertanian Kecamatan Pakisjaya mengemukakan bahwa penggunaan Kultivar Mekongga yang dipadukan dengan pengairan secara intermiten dan penyiangan secara 3 kali menghasilkan produktivitas tertinggi sebesar 7,35 Ton/Ha dibandingkan dengan Kultivar ciherang dan IPB $3 S$ (Aris, 2015).

\section{Bahan dan Metode}

Percobaan dilaksanakan di Desa Tanjung Bungin, Kecamatan Pakisjaya, Kabupaten Karawang Provinsi Jawa Barat. Ketinggian tempat percobaan adalah 5 meter di atas permukaan laut dengan jenis tanah Alluvial. Percobaan dilaksanakan di sawah irigasi pada musim kemarau selama empat bulan, yaitu mulai dari bulan September 2016 sampai dengan bulan Desember 2016.

Metode penelitian yang digunakan adalah metode eksperimen dengan rancangan percobaan adalah Rancangan Acak Kelompok. Perlakuan terdiri dari 9 kombinasi sistem tanam dan tinggi genangan yang diulang sebanyak 3 kali. Perlakuan adalah sebagai berikut: Sistem tanam $25 \times 25 \mathrm{~cm}$ dan tinggi genangan air $10 \mathrm{~cm}(\mathrm{~A})$, Sistem tanam Legowo 2:1 dan tinggi genangan air $10 \mathrm{~cm}$ (B), Sistem tanam Legowo 4:1 dan tinggi genangan air $10 \mathrm{~cm}(\mathrm{C})$, Sistem tanam $25 \mathrm{x}$ $25 \mathrm{~cm}$ dan tinggi genangan air $5 \mathrm{~cm}$ (D), Sistem tanam Legowo 2:1 dan tinggi genangan air $5 \mathrm{~cm}$ (E), Sistem tanam Legowo 4:1 dan tinggi genangan air $5 \mathrm{~cm}(\mathrm{~F})$, Sistem tanam $25 \times 25 \mathrm{~cm}$ dan tinggi genangan air $3 \mathrm{~cm}(\mathrm{G})$, Sistem tanam Legowo 2:1 dan tinggi genangan air $3 \mathrm{~cm}(\mathrm{H})$, dan Sistem tanam Legowo 4:1 dan tinggi genangan air $3 \mathrm{~cm}$ (I). Parameter yang diamati yaitu tinggi tanaman, jumlah anakan per rumpun, jumlah malai per rumpun, jumlah gabah per malai, persentasi gabah isi, bobot GKP (gabah kering panen) per rumpun, bobot GKP per petak, bobot GKG (gabah kering giling) per petak dan hasil GKG per hektar. Data dianalisis menggunakan analisis ragam dan uji lanjut dengan uji jarak berganda Duncan (Duncan Multiple Range Test/DMRT) pada taraf 5\%.

\section{Hasil dan Pembahasan}

\section{Pengamatan Penunjang}

Hasil analisis tanah sebelum percobaan menunjukkan bahwa tanah yang digunakan bertekstur liat. Sifat fisik tanah mempunyai kandungan liat $52 \%$, debu $28 \%$, dan pasir $20 \%$. Hasil analisis sifat kimia menunjukkan bahwa tanah yang digunakan mengandung $\mathrm{pH} \mathrm{H}_{2} \mathrm{O}$ sebesar 5,80 (agak masam). Selama percobaan bulan September sampai bulan Desember 2016, rata-rata suhu harian sebesar $32,3^{\circ} \mathrm{C}$, sedangkan rata-rata kelembaban udara sebesar $72,1 \%$. Pada saat tanaman berumur 5 hst mulai terjadi serangan OPT, OPT yang menyerang diantaranya keong emas (Pomacea canaliculata), dan penggerek batang (Scirpophaga innotata). Gulma yang tumbuh pada areal pertanaman adalah gulma jenis daun lebar spesies (Limnocharis flava (L. ) Buch). Saat tanaman memasuki fase berbunga gulma yang tumbuh dominan di lahan ini adalah gulma spesies (Echinocholoa crusgalli L.). Pengendalian gulma dilakukan secara mekanis, pada umur 14 hari setelah tanam (hst), 28 hst, dan 40 hst. Pengendalian dilakukan dengan cara mencabut gulma yang tumbuh menggunakan tangan dan alat kored.

\section{Pengamatan Utama}

Tinggi Tanaman. Hasil analisis ragam pengaruh sistem tanam dan tinggi genangan terhadap rata-rata tinggi tanaman umur $14 \mathrm{hst}$ (hari setelah tanam) dan 28 hst menunjukkan pengaruh tidak nyata, akan tetapi pada umur 42 hst, 56 hst, dan 70 hst memberikan pengaruh yang nyata (Tabel 1 )

Pada rata-rata tinggi tanaman umur $14 \mathrm{hst}$ dan 28 hst sistem tanam dan tinggi genangan air tidak memberikan pengaruh nyata. Hal ini diduga secara fisiologis tanaman sedang dalam proses pemulihan dan adaptasi terhadap lingkungan baru akibat proses pindah tanam 
sehingga perlakuan yang diberikan belum memberikan pengaruh terhadap tinggi tanaman. Humaeda (2009), menyatakan bahwa pada dua minggu pertama setelah penanaman merupakan saat akhir proses pemulihan (regenerasi) jaringan atau organ-organ yang rusak akibat proses transplanting (tanam pindah).

Pada rata-rata tinggi tanaman umur 42 hst sistem tanam dan tinggi genangan air memberikan pengaruh nyata. Tinggi tanaman tertinggi diperolehan perlakuan C (sistem tanam legowo 4:1 dan genangan air $10 \mathrm{~cm}$ ) sebesar $87,1 \mathrm{~cm}$, berbeda nyata dengan perlakuan E, F, G, H, dan I, akan tetapi tidak berbeda nyata dengan perlakuan lainya. Pada rata-rata tinggi tanaman umur 56 hst, sistem tanam dan tinggi genangan air memberikan pengaruh nyata. Hasil tertinggi diperolehan perlakuan C (Sistem tanam legowo 4:1 dan genangan air $10 \mathrm{~cm}$ ) sebesar 98,0 cm, berbeda nyata dengan perlakuan $\mathrm{G}, \mathrm{H}$ dan $\mathrm{I}$, akan tetapi tidak berbeda nyata dengan perlakuan A, B, D, E, dan F. Pada rata-rata tinggi tanaman umur 70 hst, sistem tanam dan tinggi genangan air memberikan pengaruh nyata. Hasil tertinggi diperolehan perlakuan C (sistem tanam legowo 4:1 dan genangan air $10 \mathrm{~cm}$ ) sebesar 107,5 cm, berbeda nyata dengan perlakuan E, F, G, H, dan I, akan tetapi tidak berbeda nyata dengan perlakuan lainya. Pada umur 42 hst, 56 hst, dan 70 hst perlakuan C (sistem tanam legowo 4:1 dan genangan air $10 \mathrm{~cm}$ ) secara konsisten memberikan pertumbuhan tinggi tanaman tertinggi di setiap umurnya. Hal ini diduga kerapatan legowo 4:1 mampu menciptakan persaingan antar tanaman untuk mendapatkan sinar matahari sehingga mendo-rong tanaman untuk tumbuh lebih tinggi pada fase vegetatif. Selain itu penggunaan Kultivar Mekongga yang memiliki kemampuan adaptasi pada cekaman air, mampu beradaptasi dengan baik pada genangan air $10 \mathrm{~cm}$ sehingga tidak mempengarui proses metabolisme tanaman di fase vegetatif. Hal ini sesuai pendapat Nurul Huda, dkk. (2012), yang menyatakan bahwa tanaman padi dapat toleran terhadap genangan di daerah perakaran karena kemampuannya untuk mengangkut oksigen secara efisien dari bagian atas tanaman ke bagian akar. Menurut Suprihatno , dkk. (2011), tinggi tanaman Kultivar Mekongga berkisar antara $101-110 \mathrm{~cm}$. Ini menunjukkan bahwa rata-rata tinggi tanaman sesuai dengan deskripsi kultivar.

Jumlah Anakan per Rumpun. Hasil analisis ragam pengaruh sistem tanam dan tinggi genangan terhadap rata-rata jumlah anakan per rumpun umur 14 hst dan 28 hst menunjukkan pengaruh tidak nyata, akan tetapi pada umur 42 hst, 56 hst, dan 70 hst memberikan pengaruh yang nyata (Tabel 2).

Pada rata-rata jumlah anakan umur 14 hst dan 28 hst sistem tanam dan tinggi genangan air tidak memberikan pengaruh nyata. Hal diduga pertumbuhan jumlah anakan pada awal pertumbuhan tanaman masih cenderung memperbaiki jaringan pada perakaran akibat pindah tanam. Menurut Rokhma (2006), dua minggu pertama setelah penanaman merupakan saat akhir proses pemulihan jaringan atau organ-organ yang rusak akibat proses transplanting (tanam pindah), sehingga proses pertumbuhan untuk jumlah anakan cenderung lambat.

Tabel 1. Rata-rata tinggi tanaman umur 14, 28, 42, 56, dan 70 hst akibat pengaruh sitem tanam dan tinggi genangan air tanaman padi Kultivar Mekongga.

\begin{tabular}{|c|c|c|c|c|c|c|c|}
\hline \multicolumn{3}{|c|}{ Perlakuan } & \multicolumn{5}{|c|}{ Rata-Rata Tinggi Tanaman (cm) } \\
\hline $\begin{array}{l}0 \\
0 \\
0 \\
1\end{array}$ & $\begin{array}{l}\text { Sistem } \\
\text { Tanam }\end{array}$ & $\begin{array}{c}\text { Tinggi } \\
\text { Genangan }\end{array}$ & 14 hst & 28 hst & 42 hst & 56 hst & 70 hst \\
\hline $\mathrm{A}$ & $25 \times 25 \mathrm{~cm}$ & $10 \mathrm{~cm}$ & $42,9 a$ & $57,5 \mathrm{a}$ & $86,0 \mathrm{ab}$ & 96,9 abc & $106,2 \mathrm{abc}$ \\
\hline $\mathrm{B}$ & Legowo 2:1 & $10 \mathrm{~cm}$ & $42,5 \mathrm{a}$ & 59,0 a & $86,3 \mathrm{ab}$ & $97,3 \mathrm{abc}$ & $106,4 \mathrm{ab}$ \\
\hline $\mathrm{C}$ & Legowo 4:1 & $10 \mathrm{~cm}$ & $44,3 \mathrm{a}$ & $58,1 \mathrm{a}$ & 87,1 a & $98,0 \mathrm{a}$ & $107,5 \mathrm{a}$ \\
\hline $\mathrm{D}$ & $25 \times 25 \mathrm{~cm}$ & $5 \mathrm{~cm}$ & $42,7 \mathrm{a}$ & $59,1 \mathrm{a}$ & $85,3 \mathrm{abc}$ & 96,1 abcd & $105,8 \mathrm{abc}$ \\
\hline $\mathrm{E}$ & Legowo 2:1 & $5 \mathrm{~cm}$ & $43,3 \mathrm{a}$ & $60,3 \mathrm{a}$ & $83,1 \mathrm{bc}$ & 95,1 abcd & $104,1 \mathrm{bcd}$ \\
\hline $\mathrm{F}$ & Legowo 4:1 & $5 \mathrm{~cm}$ & $42,8 \mathrm{a}$ & $58,0 \mathrm{a}$ & $83,3 \mathrm{bc}$ & 95,8 abcd & $103,0 \mathrm{~d}$ \\
\hline G & $25 \times 25 \mathrm{~cm}$ & $3 \mathrm{~cm}$ & $41,9 \mathrm{a}$ & $58,7 \mathrm{a}$ & $83,8 \mathrm{bc}$ & $94,1 \mathrm{~cd}$ & $102,3 \mathrm{~d}$ \\
\hline $\mathrm{H}$ & Legowo 2:1 & $3 \mathrm{~cm}$ & $41,2 \mathrm{a}$ & 55,0 a & $82,5 \mathrm{c}$ & $93,2 \mathrm{~d}$ & $104,0 \mathrm{~cd}$ \\
\hline I & Legowo 4:1 & $3 \mathrm{~cm}$ & $40,1 \mathrm{a}$ & $55,9 \mathrm{a}$ & $83,5 \mathrm{bc}$ & $94,5 \mathrm{bcd}$ & $104,2 \mathrm{bcd}$ \\
\hline & efisien Kera & $\operatorname{nan}(\%)$ & 4,2 & 3,3 & 2,0 & 1,7 & 1,2 \\
\hline
\end{tabular}

Keterangan : Angka-angka yang diikuti oleh huruf yang sama pada kolom yang sama tidak berbeda nyata menurut uji DMRT taraf $5 \%$ 
Tabel 2. Rata-rata jumlah anakan per rumpun umur 14, 28, 42, 56, dan 70 hst akibat pengaruh sitem tanam dan tinggi genangan air tanaman padi Kultivar Mekongga.

\begin{tabular}{|c|c|c|c|c|c|c|c|}
\hline \multicolumn{3}{|c|}{ Perlakuan } & \multicolumn{5}{|c|}{ Rata-Rata Jumlah Anakan per Rumpun (batang) } \\
\hline $\begin{array}{l}0 \\
0 \\
0 \\
1\end{array}$ & Sistem Tanam & $\begin{array}{c}\text { Tinggi } \\
\text { Genangan }\end{array}$ & 14 hst & 28 hst & 42 hst & 56 hst & 70 hst \\
\hline $\mathrm{A}$ & $25 \times 25 \mathrm{~cm}$ & $10 \mathrm{~cm}$ & $7,2 \mathrm{a}$ & $17,1 \mathrm{a}$ & $23,2 \mathrm{bc}$ & $18,8 \mathrm{bc}$ & $15,0 \mathrm{e}$ \\
\hline $\mathrm{B}$ & Legowo 2:1 & $10 \mathrm{~cm}$ & $7,2 \mathrm{a}$ & 18,6 a & $21,0 \mathrm{~d}$ & $18,5 \mathrm{c}$ & 15,5 de \\
\hline $\mathrm{C}$ & Legowo 4:1 & $10 \mathrm{~cm}$ & $7,2 \mathrm{a}$ & $17,3 \mathrm{a}$ & $23,7 \mathrm{~b}$ & $19,6 \mathrm{bc}$ & 16,2 cde \\
\hline $\mathrm{D}$ & $25 \times 25 \mathrm{~cm}$ & $5 \mathrm{~cm}$ & $7,1 \mathrm{a}$ & $18,8 \mathrm{a}$ & $24,8 \mathrm{ab}$ & $20,7 \mathrm{abc}$ & $17,2 \mathrm{abc}$ \\
\hline $\mathrm{E}$ & Legowo 2:1 & $5 \mathrm{~cm}$ & $7,7 \mathrm{a}$ & $20,1 \mathrm{a}$ & $24,0 \mathrm{~b}$ & $18,9 \mathrm{bc}$ & $15,7 \mathrm{de}$ \\
\hline $\mathrm{F}$ & Legowo 4:1 & $5 \mathrm{~cm}$ & $8,3 \mathrm{a}$ & $18,0 \mathrm{a}$ & $26,8 \mathrm{a}$ & $22,0 \mathrm{a}$ & $18,2 \mathrm{a}$ \\
\hline G & $25 \times 25 \mathrm{~cm}$ & $3 \mathrm{~cm}$ & $7,3 \mathrm{a}$ & $18,3 \mathrm{a}$ & $24,9 \mathrm{ab}$ & $20,8 \mathrm{a} b$ & $17,5 \mathrm{ab}$ \\
\hline $\mathrm{H}$ & Legowo 2:1 & $3 \mathrm{~cm}$ & $7,5 \mathrm{a}$ & $17,7 \mathrm{a}$ & $21,6 \mathrm{~cd}$ & $18,6 \mathrm{c}$ & $16,6 \mathrm{bcd}$ \\
\hline I & Legowo 4:1 & $3 \mathrm{~cm}$ & $6,8 \mathrm{a}$ & $16,8 \mathrm{a}$ & $25,1 \mathrm{ab}$ & $22,2, \mathrm{ab}$ & $16,7 \mathrm{ab}$ \\
\hline & efisien Keraga & n (\%) & 8,8 & 6,2 & 4,9 & 5,5 & 3,9 \\
\hline
\end{tabular}

Keterangan : Angka-angka yang diikuti oleh huruf yang sama pada kolom yang sama tidak berbeda nyata menurut uji DMRT taraf $5 \%$

Pada rata-rata jumlah anakan umur 42 hst sistem tanam dan tinggi genangan air memberikan pengaruh nyata. Jumlah anakan pada perlakuan $\mathrm{F}$ (sistem tanam Legowo 4:1 dan tinggi genangan air $5 \mathrm{~cm}$ ) sebesar 26,8 anakan per rumpun berbeda nyata dengan perlakuan $\mathrm{A}$, B, C, E dan $\mathrm{H}$, namun tidak berbeda nyata dengan perlakuan lainnya. Hal ini diduga pemberian air yang cukup dan sistem tanam yang optimal mampu menciptakan kondisi iklim mikro yang mendukung penerimaan sinar matahari lebih banyak pada fase vegetatif, sehingga proses fotosintesis yang berlangsung lebih optimal dan menghasilkan asimilat yang cukup untung mendorong pertumbuhan anakan tanaman padi.

Pada rata-rata jumlah anakan umur 56 hst sistem tanam dan tinggi genangan air memberikan pengaruh nyata. Jumlah anakan pada perlakuan $\mathrm{F}$ (sistem tanam Legowo 4:1 dan tinggi genangan air $5 \mathrm{~cm}$ ) sebesar 22,0 anakan per rumpun berbeda nyata dengan perlakuan $\mathrm{A}$, $\mathrm{B}, \mathrm{C}, \mathrm{E}$, dan $\mathrm{H}$, namun tidak berbeda nyata dengan perlakuan lainnya. Pada rata-rata jumlah anakan umur 70 hst sitem tanam dan tinggi genangan air memberikan pengaruh nyata. Jumlah anakan pada perlakuan $\mathrm{F}$ (sistem tanam Legowo 4:1 dan tinggi genangan air $5 \mathrm{~cm}$ ) sebesar 18,2 anakan per rumpun berbeda nyata dengan perlakuan $\mathrm{A}, \mathrm{B}, \mathrm{C}, \mathrm{D}, \mathrm{E}$ dan $\mathrm{H}$, namun tidak berbeda nyata dengan perlakuan lainnya. Pada umur 56 hst dan 70 hst terjadi penurunan jumlah anakan, hal ini diduga terjadi akibat tanaman padi mulai memasuki fase generatif, dimana fungsi fisiologis tanaman sedikit terganggu sehingga mempengaruhi pemben- tukan jaringan pertumbuhan pada akhir fase vegetatif. Menurut Anwar (2008), bertambahnya umur tanaman setelah memasuki periode generatif selalu diiringi dengan menurunnya kemampuan berbagai fungsi fisiologis tanaman sehingga kelangsungan organ-organ vegetatif cenderung menurun termasuk menurunnya jumlah anakan tidak produktif dan berbagai fungsi fisiologis akar. Menurut Kasim (2004) genangan dapat menekan pertumbuhan anakan pada tanaman padi, hal ini dikarenakan kurangnya ruang udara bagi anakan untuk muncul ke permukaan ditekan oleh genangan air tersebut, namun di sisi lain genangan menguntungkan bagi tanaman padi karena penggunaan asimilat dapat lebih difokuskan pada produktivitas gabah ketika anakan tertekan dan tidak tumbuh dengan maksimal.

\section{Komponen Hasil}

Jumlah Malai Per Rumpun dan Jumlah Gabah Per Malai. Hasil analisis ragam pengaruh sistem tanam dan tinggi genangan terhadap jumlah malai per rumpun dan jumlah gabah per malai menunjukkan pengaruh yang nyata (Tabel 3)

Pada rata-rata jumlah malai per rumpun, sistem tanam dan tinggi genangan air memberikan pengaruh yang nyata. Jumlah malai per rumpun pada perlakuan $\mathrm{F}$ (Legowo 4:1 dan tinggi genangan air $5 \mathrm{~cm}$ ) sebesar 16,3 malai, berbeda nyata dengan perlakuan A, B, dan $\mathrm{E}$, namun tidak berbeda nyata dengan perlakuan lainnya. Hal ini diduga sistem tanam legowo 4: 1 mampu memberikan kondisi iklim mikro yang baik pada fase vegetatif sehingga 
laju fotosintesis, respirasi, aktivitas enzim berjalan optimal, walaupun dikombinasikan dengan pengairan yang berbeda, yang akan mempengaruhi besar kecilnya produksi malai suatu tanaman. Menurut Hasanuddin (2004), produksi suatu malai merupakan salah satu penambahan berat kering suatu tanaman. Besarkecilnya produksi malai suatu tanaman sangat tergantung pada faktor-faktor pertumbuhan. Menurut Balai Litbang Pertanian Jawa Barat, (2011). Pengairan yang diberikan secara kecukupan akan memberi kesempatan kepada akar untuk berkembang menjadi lebih baik.

Pada rata-rata jumlah gabah per malai, sistem tanam dan tinggi genangan air memberikan pengaruh yang nyata. Jumlah gabah per malai perlakuan $\mathrm{F}$ (sistem tanam Legowo 4:1 dan tinggi genangan air $5 \mathrm{~cm}$ ) sebesar 142,7 butir, berbeda nyata dengan perlakuan A, B, C, E, dan G namun tidak berbeda nyata dengan perlakuan lainya. Hal ini diduga jumlah gabah sangat berbanding lurus lurus dengan jumlah malai pada stadia masak, sehingga banyaknya suatu rumpun sangat menentukan hasil panen secara keseluruhan, ini terlihat dari hasil yang dicapai oleh sistem tanam Legowo 4:1 dan tinggi genangan air $5 \mathrm{~cm}$ memberikan hasil yang konsisten, baik jumlah malai maupun jumlah gabah per malai.

Persentasi Gabah Isi, Bobot GKP Per Rumpun, Bobot GKP Per Petak, Bobot GKG Per Petak dan Hasil GKG Per Hektar. Hasil analisis ragam pengaruh sistem tanam dan tinggi genangan terhadap persentase gabah isi, bobot GKP per rumpun, bobot GKP per petak, bobot GKG per petak dan hasil GKG per Hektar tanaman padi Kultivar Mekonga, menunjukkan pengaruh yang nyata (Tabel 4).

Pada rata-rata persentase gabah isi, sistem tanam dan tinggi genangan air memberikan pengaruh yang nyata. Persentase gabah isi perlakuan F (sistem tanam Legowo 4:1 dan tinggi genangan air $5 \mathrm{~cm}$ ) sebesar 95,8 persen, berbeda nyata dengan perlauan $A, B$,E dan $H$, namun tidak berbeda nyata dengan perlakuan lainya. Hal ini diduga karena sistem tanam Legowo 4:1 dan tinggi genangan air $5 \mathrm{~cm}$ memberikan ketersediaan air yang cukup untuk kebutuhan tanaman pada fase vegetatif dan mengurangi terjadinya plasmolisis, sehingga saat memasuki fase generatif, ketersediaan air yang cukup mampu mengoptimalkan proses potosintesis yang mengakibatkan proses pengisian gabah menjadi lebih optimal. Menurut Bouman, B. A. M dalam Devi (2011), kekurangan dan kelebihan air dapat mengganggu proses metabolisme bahkan akan mematikan tanaman.

Pada rata-rata bobot GKP per rumpun, sistem tanam dan tinggi genangan air memberikan pengaruh yang nyata. Bobot GKP per rumpun perlakuan F (sistem tanam Legowo 4:1 dan tinggi genangan air $5 \mathrm{~cm}$ ) sebesar $254,7 \mathrm{~g}$ per rumpun, berbeda nyata dengan perlakuan A, B, C, D, dan E, namun tidak berbeda nyata dengan perlakuan lainnya. Hal ini diduga tingginya perolehan hasil gabah pada perlakuan $\mathrm{F}$ ditunjang oleh perolehan jumlah malai produktif lebih banyak dibanding perlakuan lainnya, selain itu pemberian air yang semakin sedikit menunjukkan produktivitas hasil tanaman yang semakin besar, terlihat pada setiap perlakuan tinggi genangan $10 \mathrm{~cm}$ secara berturutturut menghasilkan bobot gabah kering panen per rumpun lebih kecil dibandingkan tinggi genangan $5 \mathrm{~cm}$ atau $3 \mathrm{~cm}$ yang menghasilkan bobot gabah

Tabel 3. Rata rata jumlah malai per rumpun dan jumlah gabah per malai akibat pengaruh sistem tanam dan tinggi genangan air tanaman padi Kultivar Mekongga.

\begin{tabular}{|c|c|c|c|c|}
\hline \multirow[t]{2}{*}{ Kode } & \multicolumn{2}{|c|}{ Perlakuan } & \multirow{2}{*}{$\begin{array}{l}\text { Jumlah Malai per Rumpun } \\
\text { (malai) }\end{array}$} & \multirow{2}{*}{$\begin{array}{c}\text { Jumlah Gabah per Malai } \\
\text { (butir) }\end{array}$} \\
\hline & Sistem Tanam & Tinggi Genangan & & \\
\hline $\mathrm{A}$ & $25 \times 25 \mathrm{~cm}$ & $10 \mathrm{~cm}$ & $13,4 \mathrm{~d}$ & $133,3 \mathrm{bc}$ \\
\hline B & Legowo 2:1 & $10 \mathrm{~cm}$ & $14,6 \mathrm{bc}$ & $129,9 \mathrm{bc}$ \\
\hline $\mathrm{C}$ & Legowo 4:1 & $10 \mathrm{~cm}$ & $15,0 \mathrm{abc}$ & $133,2 \mathrm{bc}$ \\
\hline $\mathrm{D}$ & $25 \times 25 \mathrm{~cm}$ & $5 \mathrm{~cm}$ & $15,9 \mathrm{ab}$ & $135,8 \mathrm{abc}$ \\
\hline $\mathrm{E}$ & Legowo 2:1 & $5 \mathrm{~cm}$ & $14,5 \mathrm{~cd}$ & $126,5 \mathrm{c}$ \\
\hline $\mathrm{F}$ & Legowo 4:1 & $5 \mathrm{~cm}$ & $16,3 \mathrm{a}$ & $142,7 \mathrm{a}$ \\
\hline G & $25 \times 25 \mathrm{~cm}$ & $3 \mathrm{~cm}$ & $15,7 \mathrm{abc}$ & $129,2 \mathrm{bc}$ \\
\hline $\mathrm{H}$ & Legowo 2:1 & $3 \mathrm{~cm}$ & $15,8 \mathrm{abc}$ & $133,9 \mathrm{abc}$ \\
\hline I & Legowo 4:1 & $3 \mathrm{~cm}$ & $16,2 \mathrm{a}$ & $137,1 \mathrm{ab}$ \\
\hline \multicolumn{3}{|c|}{ Koefisien Keragaman (\%) } & 4,58 & 3,68 \\
\hline
\end{tabular}

Keterangan : Angka-angka yang diikuti oleh huruf yang sama pada kolom yang sama tidak berbeda nyata menurut uji DMRT taraf $5 \%$ 
Tabel 4. Rata-rata bobot GKP per rumpun, bobot GKP per petak, bobot GKG per petak dan hasil GKG per Hektar akibat pengaruh sistem tanam dan tinggi genangan air tanaman padi (Oryza sativa L. ) Kultivar Mekongga.

\begin{tabular}{|c|c|c|c|c|c|c|c|}
\hline \multirow{3}{*}{$\underset{0}{0}$} & \multicolumn{2}{|c|}{ Perlakuan } & \multirow{2}{*}{$\begin{array}{c}\text { Persentase } \\
\text { gabah Isi }\end{array}$} & \multirow{2}{*}{$\begin{array}{l}\text { Bobot GKP } \\
\text { per Rumpun }\end{array}$} & \multirow{2}{*}{$\begin{array}{c}\text { Bobot GKP } \\
\text { per Petak } \\
(3 \times 7) \mathrm{m}\end{array}$} & \multirow{2}{*}{$\begin{array}{c}\text { Bobot GKG } \\
\text { per Petak } \\
(3 \times 7) \mathrm{m}\end{array}$} & \multirow{2}{*}{$\begin{array}{l}\text { Hasil GKG } \\
\text { per Hektar }\end{array}$} \\
\hline & \multirow[t]{2}{*}{ Sistem tanam } & \multirow[t]{2}{*}{$\begin{array}{c}\text { Tinggi } \\
\text { Genangan }\end{array}$} & & & & & \\
\hline & & & $(\%)$ & (gram) & $(\mathrm{kg})$ & $(\mathrm{kg})$ & (ton) \\
\hline $\mathrm{A}$ & $25 \times 25 \mathrm{~cm}$ & $10 \mathrm{~cm}$ & $89,1 \mathrm{c}$ & $191,7 \mathrm{c}$ & $14,1 \mathrm{~d}$ & $12,7 \mathrm{c}$ & 6,0 \\
\hline B & Legowo 2:1 & $10 \mathrm{~cm}$ & $91,7 \mathrm{bc}$ & $199,1 \mathrm{c}$ & $14,4 \mathrm{~d}$ & $12,9 \mathrm{c}$ & 6,1 \\
\hline $\mathrm{C}$ & Legowo 4:1 & $10 \mathrm{~cm}$ & $92,0 \mathrm{abc}$ & $217,7 \mathrm{bc}$ & $14,8 \mathrm{~cd}$ & $13,5 \mathrm{bc}$ & 6,4 \\
\hline $\mathrm{D}$ & $25 \times 25 \mathrm{~cm}$ & $5 \mathrm{~cm}$ & $94,0 \mathrm{ab}$ & $202,9 c$ & $14,8 \mathrm{~cd}$ & $13,9 \mathrm{abc}$ & 6,6 \\
\hline $\mathrm{E}$ & Legowo 2:1 & $5 \mathrm{~cm}$ & $90,3 \mathrm{bc}$ & $211,9 c$ & $15,9 a b c$ & $14,4 \mathrm{ab}$ & 6,9 \\
\hline $\mathrm{F}$ & Legowo 4:1 & $5 \mathrm{~cm}$ & $95,8 \mathrm{a}$ & $254,7 \mathrm{a}$ & $16,4 \mathrm{a}$ & $15,2 \mathrm{a}$ & 7,2 \\
\hline G & $25 \times 25 \mathrm{~cm}$ & $3 \mathrm{~cm}$ & $92,3 a b c$ & $227,3 \mathrm{abc}$ & $15,2 \mathrm{bcd}$ & $14,5 \mathrm{ab}$ & 6,9 \\
\hline $\mathrm{H}$ & Legowo 2:1 & $3 \mathrm{~cm}$ & $91,4 \mathrm{bc}$ & $226,4 \mathrm{abc}$ & $15,7 \mathrm{abc}$ & $15,0 \mathrm{a}$ & 7,1 \\
\hline $\mathrm{I}$ & Legowo 4:1 & $3 \mathrm{~cm}$ & $93,6 \mathrm{ab}$ & $248,8 \mathrm{ab}$ & $16,1 \mathrm{ab}$ & $14,7 \mathrm{ab}$ & 7,0 \\
\hline & Koefisien Kerag & $\operatorname{nan}(\%)$ & 2,25 & 8,36 & 4,26 & 4,85 & \\
\hline
\end{tabular}

Keterangan : Angka-angka yang diikuti oleh huruf yang sama pada kolom yang sama tidak berbeda nyata menurut uji DMRT taraf $5 \%$

kering panen per rumpun lebih tinggi. Hal ini sesuai dengan Anwar (2008), salah satu faktor yang mempengaruhi peningkatan hasil gabah adalah meningkatnya nilai komponen hasil. Rumaropen (2012), menjelaskan bahwa pengairan secara cukup akan memberikan dampak terhadap hasil tanaman, pada fase pematangan, air yang diperlukan semakin sedikit dan berangsur-angsur sampai sama sekali kering pada periode matang kuning, sehingga drainase perlu dilakukan. Namun, pengeringan yang terlalu awal akan mengakibatkan bertambahnya gabah hampa dan beras pecah.

Pada rata-rata bobot GKP per petak, sistem tanam dan tinggi genangan air memberikan pengaruh yang nyata. Hasil tertinggi diperolehan perlakuan $\mathrm{F}$ (sistem tanam Legowo 4:1 dan tinggi genangan air $5 \mathrm{~cm}$ ) sebesar $16,4 \mathrm{~kg}$ per petak, berbeda nyata dengan perlakuan $\mathrm{A}, \mathrm{B}$, C, D, dan G, namun tidak berbeda nyata dengan perlakuan lainnya. Hal ini diduga sistem tanam Legowo 4:1 dan tinggi genangan air $5 \mathrm{~cm}$ mampu meningkatkan kadar oksigen dalam tanah, sehingga pertumbuhan jumlah anakan produktif per rumpun dan hasil padi per hektar menjadi lebih maksimal. Hal ini menunjukkan tanaman padi Kultivar Mekongga dapat berproduksi dengan baik pada penggenangan kurang dari $10 \mathrm{~cm}$, sehingga ketersediaan air untuk proses metabolismenya tercukupi yang akan mendukung peningkatan komponen hasil dan hasil tanaman padi. Makarim dan Ikhwani (2012), bahwa peningkatan hasil gabah dapat dipengaruhi oleh komponen hasil lainnya yaitu jumlah anakan produktif, jumlah malai per rumpun, serta laju pengisian gabah yang lebih efisien sehingga mempunyai presentasi gabah isi yang lebih tinggi

Pada rata-rata bobot GKG per petak, sistem tanam dan tinggi genangan air memberikan pengaruh yang nyata. Hasil tertinggi diperolehan perlakuan F (sistem tanam Legowo 4:1 dan tinggi genangan air $5 \mathrm{~cm}$ ) sebesar $15,2 \mathrm{~kg}$ per petak, berbeda nyata dengan perlakuan $\mathrm{A}, \mathrm{B}$, dan $C$, namun tidak berbeda nyata dengan perlakuan lainya. Hal ini diduga tinggi genangan lebih memberikan pengaruh terhadap komponen pertumbuhan dan hasil, ini terlihat dari tinggi genangan kurang dari $10 \mathrm{~cm}$ secara konsisten memberikan komponen pertumbuhan dan hasil terbaik, sebaliknya tinggi genangan air $10 \mathrm{~cm}$ justru cenderung menurunkan komponen pertumbuhan dan hasil. Menurut Rokhma (2006) tanaman padi bukanlah tanaman air (hidrophyta) sehingga penggunaan air secara berlebih mampu menurunkan kualitas dan kuantitas hasil tanaman. Bila irigasi diberikan setelah kelembaban tanah mencapai titik kritisnya maka tanaman akan mengalami cekaman air (stress air) yang dapat mempengaruhi pertumbuhan dan produktivitas tanaman. (Bouman dalam Devi, 2011). Hal ini menunjukan sistem tanam legowo 4:1 dan genangan air $5 \mathrm{~cm}$ mampu memberikan kondisi iklim mikro dan ketersediaan air yang cukup pada fase vegetatif dan generatif yang sesuai bagi tanaman padi Kultivar Mekongga, sehingga 
faktor internal dan eksternal yang mempengaruhi tumbuh kembangnya memberikan efek yang optimal, ini terlihat dari komponen pertumbuhan berbanding lurus dengan komponen hasil yang dicapai oleh sistem tanam Legowo 4:1 dan tinggi genangan air $5 \mathrm{~cm}$ sebesar 15,2 kg per petak atau setara dengan 7,2 ton per hektar.

\section{Kesimpulan}

Kombinasi sistem tanam dan tinggi genangan air tanaman padi Kultivar Mekongga memberikan pengaruh yang nyata terhadap tinggi tanaman 42 hst, 56 hst, dan 70 hst. Jumlah anakan umur 42 hst, 56 hst, dan 70 hst, jumlah malai per rumpun, jumlah gabah per malai, persentase gabah isi, bobot gabah kering panen per rumpun, bobot gabah kering panen per petak, bobot gabah kering giling per petak. Sistem tanam legowo 4:1 dengan tinggi genangan air $5 \mathrm{~cm}$ memberikan hasil gabah kering giling tertinggi sebanyak $15,2 \mathrm{~kg} /$ petak atau setara dengan produktivitas 7,20 ton/ha.

\section{Daftar Pustaka}

Anwar, K. 2008. Tata Air untuk Peningkatan Produksi Padi pada Tanah Sulfat Masam. Prosiding Simposium V Tanaman Pangan - Inovasi Teknologi Tanaman Pangan. Pusat Penelitian dan Pengembangan Tanaman Pangan, Badan Penelitian dan Pengembangan Pertanian. Vol 2: 388-397.

Aqil, 2007.Peluang Peningkatan Produksi Pangan Melalui Penerapan Konsep Produktivitas Air Tanaman. Balai Penelitian Tanaman Serealia: Maros.

Badan Pusat Statstika. 2016. Statistik Indonesia 2016. Badan Pusat Statistik. Jawa Barat

Balai Irigasi, 2007. Pengelolaan Irigasi Hemat Air untuk Padi Sawah Melalui Metode System of Rice Intensification (SRI). Pelatihan cara pengamatan dalam rangka penelitian irigasi hemat air pada budi daya padi dengan metode SRI. Pusat Penelitian Dan Pengembangan Sumberdaya Air. Bekasi.

Balai Litbang Pertanian Jawa Barat. 2011. Sekolah Lapang Pengelolaan Tanaman Terpadu. Lembang Bandung Barat.
Bouman, B. A. M. , R. M. Lampayan, and T. P. Tuong. 2007. Water Management in Irrigated Rice, Croping With Water Scarcity. International Rice Research Institute. http://www. irri. org.[6 Februari 2010].Terjemahan Devi Novi Astuti.2011. Pengaruh Sistem Pengairan terhadap Pertumbuhan dan Hasil Tanaman Padi Sawah.Institut Pertanian Bogor. Bogor.

Devi Novi Astuti. 2011.Pengaruh Sistem Pengairan Terhadap Pertumbuhan dan Hasil Tanaman Padi Sawah.Institut Pertanian Bogor. Skripsi (Tidak dipublikasikan).

Gani, S. 2007. Perencanaan Sistem Irigasi Rotasi untuk Penyaluran Air Secara Proporsional. Alami Vol. 12

Hasanuddin, 2004. Pengelolaan Tanaman Padi Terpadu Suatu Strategi Pendekatan Teknologi Spesifik Lokasi. Makalah Disampaikan pada Pelatihan Pengembangan Kultivar Unggul Tipe Baru (VUTB) Fatmawati dan VUTB Lainnya 31 Maret - 3 April 2004, di Balitpa, Sukamandi.

Humaeda. 2009. Kultivar Unggul Padi Baru. http:// www. litbang. deptan. go. id/ artikel/one/241/pdf/

Juliardi, Iwan, dan A. Ruskandar. 2006. Teknik Mengairi Padi: kalau Macak-macak Cukup, Mengapa Harus Digenang. http://www. pustaka-deptan. go. id/publikasi/p3213024. pdf. [18 Juni 2015].

Kasim, M. 2004. Manajemen Penggunaan Air Meminimalkan Penggunaan Air untuk Meningkatkan Produksi Padi Sawah Melalui Sistem Intensifikasi Padi (The System of riceintensification-SRI). Pidato Pengukuhan Sebagai Guru Besar Unand. Padang, Sumatra Barat.

Makarim, A. K. dan Ikhwani. 2012. Teknik Ubinan, Pendugaan Produktivitas Padi Menurut Sistem tanam. Puslitbangtan. $44 \mathrm{p}$.

Makarim, E.Suhartatik, dan A.Kartohardjono. 2007. Hara Penting Pada Sistem Produksi Padi. Penelitian Balai Besar tanaman padi.Subang.

Pitoyo, J. 2013. Mesin Penyiang Gulma Padi Sawah Bermotor. Sinar Tani. Edisi 5-11 Juli 2006. http://www. pustaka-deptan. go. id. Akses tanggal 9 juli 2007. 
Putra, S.2011. Pengaruh Sistem tanam terhadap Peningkatan Hasil Padi Gogo Kultivar Situpatenggang. J. Agrin. 15(1):54-63.

Rokhma, 2006.Menyelamatkan Pangan dengan Irigasi Hemat Air.Impulse.Yogyakarta.

Rumaropen, N. 2012. Studi Evaluasi kapasitas Pengalirandan Pola Tata Guna Air pada Daerah Irigasi LerehKabupaten Jayapura. Tesis tidak dipubikasikan. Universitas Brawijaya Malang.

Suhartatik, E., A. K. Makarim, dan Ikhwani. 2011. Respon Lima Kultivar Unggul Baru terhadap Perubahan Sistem tanam. Inovasi Tekonologi Padi Mengantisipasi Cekaman Lingkungan Biotik dan Abiotik.Prosiding seminar Nasional hasil penelitian Padi 2011.p. 1259- 1273.

Suprihatno B, Aan A. Daradjat, Satoto, Baehaki, N. Widiarta, A. Setyono, S. D. Indrasari, O. S. Lesmana, H. Sembiring.2011. Deskripsi Kultivar padi, Badan Penelitian dan Pengembangan Pertanian, Balai Besar Penelitian Tanaman Padi, Sukamandi. 78p

Uphoff, N. 2002. Opportunities for Raising Yields by Changing Management Practices: The
System of Rive Intensification in Madagascar. Agroecological Innovation. London: Earthscan Publication Ltd. Terjemahan Oscar Regazzoni, Yogi Sugito, Agus Suryanto. 2013. Sistem irigasi berselang (intermittent irrigation) pada budidaya padi (oryza sativa 1. )Kultivar inpari-13 dalam pola sri (system of rice intensification). Jurusan Budidaya Pertanian,Fakultas Pertanian, Universitas Brawijaya. J. Tanaman Pangan 1 (2) : 2338-3976

Yudhi Mahmud, Sulistyo Sidik Purnomo. 2014. Keragaman agronomis beberapa Kultivar Unggul baru tanaman padi (Oryza sativa 1. ) Pada model pengelolaan tanaman terpadu FakultasPertanian Program Studi Agroteknologi Universitas Singaperbangsa Karawang Jurnal Ilmiah Solusi Vol. 1 No. 1 Januari - Maret 2014: 1-10

Zaini, Z. 2008. Memacu Peningkatan Produksi Padi Sawah melalui Inovasi Teknologi Budidaya Spesifik Lokasi dalam Era Revolusi Hijau Lestari. Orasi Pengukuhan Profesor Riset Bidang Budidaya Tanaman, Bogor. 56 Hal. 